\title{
KORELASI PENGATURAN UPAH DENGAN INVESTASI DI INDONESIA
}

\author{
Oleh : \\ Noor Faiz ${ }^{1}$
}

\begin{abstract}
Wages regulating system is one of the things that affect investment because business actors expect to gain maximum profit with minimal cost. This study aims to determine the correlation of wage policy and investment in Indonesia. Type of research used in this research is normative / doctrinal legal research with legal approach. From this study it can be seen that to create a balance between wage rights and business actor's interests, the government sets wages regulation that protect workers based on the needs of decent living with attention to productivity and economic growth. The wage system needs to be developed considering the balance between achievement or productivity, worker needs and company capacity.
\end{abstract}

Keywords: wage, investment, balance

\begin{abstract}
Abstrak
Pengaturan upah merupakan salah satu hal yang dapat memengaruhi investasi karena lazimnya pelaku usaha mengharapkan memperoleh keuntungan maksimal dengan modal minimal. Penelitian ini bertujuan untuk mengetahui kebijakan pengupahan terkait dengan investasi di Indonesia. Jenis penelitian yang digunakan dalam penelitian ini adalah penelitian hukum normatif/doktrinal dengan pendekatan perundang-undangan. Dari penelitian ini dapat diketahui bahwa untuk menciptakan keseimbangan hak upah dengan kepentingan pelaku usaha, pemerintah menetapkan pengaturan pengupahan yang melindungi pekerja/ buruh berdasarkan kebutuhan hidup layak dengan memperhatikan produktivitas dan pertumbuhan ekonomi. Sistem pengupahan perlu dikembangkan dengan memperhatikan keseimbangan antara prestasi atau produktivitas kerja, kebutuhan pekerja dan kemampuan perusahaan.
\end{abstract}

Kata kunci: upah, penanaman modal, investasi, keseimbangan.

\section{PENDAHULUAN}

Pembangunan nasional di Indonesia adalah sebagai salah satu cara mewujudkan kesejahteraan bagi bangsa Indonesia sebagaimana amanat dalam Undang-Undang Dasar Negara Kesatuan Republik Indonesia Tahun
1945 (selanjutnya disebut UUD 1945). Sebagai negara bercorak civil law yang menghendaki agar hukum yang ada dituangkan dalam bentuk tertulis, amanat dalam UUD 1945 tersebut telah dijabarkan dalam berbagai peraturan perundangan-undangan.Pembangunan

1 Hakim Pengadilan Agama Badung, Bali, email : faizbusholic@gmail.com. 
merupakan proses yang kompleks karena menghendaki keterlibatan segala aspek kehidupan yang saling bersinergi dan berkesinambungan dalam rangka mencapai tujuan yang sama. ${ }^{2}$

UUD 1945 menyatakan bahwa pembangunan ekonomi mengisyaratkan adanya peran serta dari masyarakat. Hal tersebut dapat dilihat dari Pasal 33 ayat (4) UUD 1945 yang berbunyi "Perekonomian nasional diselenggarakan atas dasar demokrasi ekonomi dengan prinsip kebersamaan, efisiensi berkeadilan, berkelanjutan, berwawasan lingkungan, kemandirian, serta dengan menjaga keseimbangan kemajuan dan kesatuan ekonomi nasional". 3 Makna dari prinsip kebersamaan yang tercantum dalam Pasal 33 ayat (4) UUD 1945 tersebut harus dilihat secara komprehensif. Ini berarti bahwa pembangunan menghendaki tidak hanya peran pemerintah akan tetapi peran masyarakat juga. Atas dasar itu maka dibentuk lah Undang-Undang Nomor 25 Tahun 2007 tentang Penanaman Modal.

Penanaman modal berkaitan erat dengan pemenuhan kebutuhan masyarakat. Penanaman modal berpeluang membentuk bidang pekerjaan yang akan dapat menyerap tenaga kerja ke dalamnya. UndangUndang Penanaman Modal di

2 Ibid., hlm. 21.

3 Jonker Sihombing, 2010, Peran dan Aspek Hukum dalam Pembangunan Ekonomi, Alumni, Bandung, hlm. 74. samping mengatur penanaman modal secara umum, juga mengatur tentang ketenagakerjaan yang dapat ditemukan dalam Pasal 10 dan Pasal 11. Pengaturan pengupahan tenaga kerja diatur secara khusus dalam UndangUndang Nomor 13 Tahun 2003 tentang KetenagakerjaandanPeraturanMenteri Tenaga Kerja dan Transmigrasi Nomor 7 Tahun 2013 tentang Upah Minimum. Dalam Pasal 88 UndangUndang Ketenagakerjaan tersebut ditentukan bahwa setiap pekerja/buruh berhak memperoleh penghasilan yang memenuhi penghidupan yang layak bagi kemanusiaan. Di samping itu juga diatur bahwa pemerintah menetapkan pengaturan pengupahan yang melindungi pekerja/buruh berdasarkan kebutuhan hidup layak dengan memperhatikan produktivitas dan pertumbuhan ekonomi.

Dari latar belakang tersebut, rumusan masalah dalam penelitian ini adalah pertama bagaimanakah pengaturan investasi dan pengupahan di Indonesia?, kedua bagaimanakah korelasi pengaturan pengupahan dengan investasi di Indonesia?

Dalam penelitian ini, penulis menggunakan bahan hukum berupa peraturan perundangan-undangan dan literatur hukum yang relevan dengan permasalahan yang diteliti. Penulis menyadari bahwa penelitian ini memiliki kesamaan topik dengan penelitian lainnya akan tetapi terdapat perbedaan dalam objek pembahasan. Adapun penelitian yang terkait dengan 
topik penelitian yang penulis teliti antara lain:

1. Pengaturan Upah Berdasarkan Prinsip Keadilan, penulis: Yetniwati, Universitas Gadjah Mada, Yogyakarta, tahun 2017. Hasil penelitian tersebut antara lain menyimpulkan bahwa pembentukan Peraturan Pemerintah Nomor 78 Tahun 2015 tidak melibatkan lembaga tripartit sehingga tidak adil bagi pekerja dan perumusan asas hukum pengupahan yang berkeadilan.

2. Ketidakseimbangan Hak dan Kewajiban Antara Investor Asing dengan Pekerja Indonesia dalam Pengaturan Penanaman Modal dan Ketenagakerjaan, penulis Sulistiowati, Universitas Gadjah Mada, Yogyakarta, tahun 2015. Hasil penelitian tersebut menyimpulkan bahwa ada ketidakseimbangan antara investor asing dengan pekerja Indonesia yang tampak dalam kesamaan upah pekerja Indonesia yang bekerja pada PMA dan PMDN.

Tujuan dari penelitian ini adalah untuk mengetahui kebijakan pengupahan terkait dengan investasi di Indonesia.

\section{METODE PENELITIAN}

Jenis penelitian dalam penelitian ini adalah penelitian hukum normatif. Penelitian hukum normatif dikenal juga dengan istilah penelitian hukum doktrinal yang merupakan penelitian yang bertujuan memberikan penjelasan yang terperinci atas isu hukum yang dihadapi. ${ }^{4}$ Sedangkan jenis pendekatan yang digunakan adalah pendekatan peraturan perundang-undangan. Dalam penelitian hukum normatif, permasalahan dikaji berdasarkan peraturan perundang-undangan yang berlaku dan konsep/teori hukum digunakan sebagai pisau analisis untuk mencari pemecahan masalah.

\section{HASIL PEMBAHASAN}

Salah satu sisi yang paling rawan konflik antara pengusaha dan pekerja dalam hubungan industrial adalah pengupahan. Di satu sisi upah merupakan hak pekerja/buruh yang berfungsi sebagai imbalan atas jasa dan/atau tenaga yang mereka lakukan, tetapi upah merupakan komponen yang harus dikeluarkan oleh pengusaha. Dengan adanya sudut pandang berbeda tersebut maka agar hak pekerja/buruh terhadap penghasilannya tersebut terlindungi, pemerintah menetapkan upah minimum.

Dengan demikian maka dapat dilihat bahwa investasi memiliki hubungan dengan ketenagakerjaan, terlebih dengan pengupahan. Investor mempunyai kepentingan terhadap pekerja/buruh agar investasi nya dapat berjalan dan berkembang. Sedangkan pekerja/buruh berkepentingan untuk

4 Dyah Ochtorina Susanti dan A'an Efendi, 2014, Penelitian Hukum (Legal Research), Sinar Grafika, Jakarta, hlm 11 
mendapatkan kesempatan memperoleh pekerjaan dan upah yang layak bagi kehidupannya.

\subsection{Pengaturan Upah di Indonesia}

Upah menurut Undang-Undang Nomor 13 Tahun 2003 tentang Ketenagakerjaan adalah hak pekerja/ buruh yang diterima dan dinyatakan dalam bentuk uang sebagai imbalan dari pengusaha atau pemberi kerja kepada pekerja/buruh. Pasal 1 angka 30 UU Ketenagakerjaan menentukan bahwa upah tersebut ditetapkan atau dibayarkan menurut suatu perjanjian kerja, kesepakatan, atau peraturan perundang-undangan, termasuk tunjangan bagi pekerja/buruh dan keluarganya atas suatu pekerjaan dan/atau jasa yang telah atau akan mereka lakukan. Upah merupakan salah satu sarana bagi pekerja untuk meningkatkan kesejahteraannya. ${ }^{5}$

Upah itu sendiri adalah hak pekerja/buruh yang semestinya dapat digunakan untuk mencukupi kebutuhan hidup mereka beserta keluarganya. Pengembangan sistem pengupahan sedapat mungkin dilakukan dengan memperhitungkan adanya keseimbangan antara prestasi atau produktivitas kerja, kebutuhan pekerja, serta kemampuan perusahaan. Selain itu perlu juga agar struktur upah dikembangkanmenjadilebihsederhana sekaligus memuat komponen upah

5 Asri Wijayanti, 2016, Hukum Ketenagakerjaan Pascareformasi, Sinar Grafika, Jakarta, hlm. 107. yang jelas sesuai dengan kebutuhan. Mekanisme penetapan upah dan kenaikan upah sebaiknya diatur dalam perjanjian kerja, peraturan perusahaan, atau perjanjian kerja bersama antara pengusaha dengan pekerja/buruh.

Pengaturan pengupahan di Indonesia diatur dalam Pasal 88 hingga Pasal 98 Undang-Undang Nomor 13 Tahun 2003 tentang Ketenagakerjaan (UU Ketenagakerjaan). Kemudian di tingkat teknis, pengupahan diatur dalam Peraturan Pemerintah Nomor 78 Tahun 2015 tentang Pengupahan dan Peraturan Menteri Nomor 7 Tahun 2013 tentang Upah Minimum. Dasar pengupahan adalah pekerjaan yang dilakukan oleh pekerja/buruh. Pasal 93 ayat (1) Undang-Undang Ketenagakerjaan menentukan bahwa upah tidak dibayar apabila pekerja/ buruh tidak melakukan pekerjaan.

Penghasilan pekerja/buruh diberikan atas dasar untuk pemenuhan penghidupan yang layak, sebagaimana diatur dalam Pasal 88 Undang-Undang Ketenagakerjaan. Penghasilan yang dapat memenuhi kebutuhan hidup yang layak merupakan jumlah penerimaan atau pendapatan pekerja/buruh atas hasil pekerjaannya yang dapat digunakan untuk mencukupikebutuhan hidup pekerja/buruh dan keluarganya secara proporsional yang meliputi kebutuhan makan dan minum, pakaian, tempat tinggal, pendidikan, kesehatan, rekreasi, dan jaminan hari tua. Dan untuk mendapatkan penghasilan yang dapat digunakan untuk memenuhi 
tercapainya kehidupan yang layak, pemerintah telah menentukan kebijakan pengupahan agar mampu memberi perlindungan kepada pekerja/ buruh dengan cara mengatur mengenai upah minimum, upah kerja lembur, dan sebagaimana diatur dalam Pasal 90 UU Ketenagakerjaan.

Kebijakan upah minimum ditetapkan oleh pemerintah sesuai dengan pemenuhan kebutuhan hidup layak dan dengan memperhatikan tingkat produktivitas dan pertumbuhan ekonomi. Dan upah minimum tersebut dapat terdiri atas upah minimum menurut wilayah provinsi atau kabupaten/kota dan upah minimum menurut sektor dalam wilayah provinsi atau kabupaten/kota. Upah minimum diarahkan pada terwujudnya pencapaian pemenuhan kebutuhan hidup layak. Kemudian Gubernur dalam menetapkan pengaturan upah minimum dengan memperhatikan rekomendasi dari Dewan Pengupahan Provinsi dan/atau Bupati/Walikota. Sedangkan komponen dan pelaksanaan tahapan pencapaian kebutuhan hidup layak diatur melalui Keputusan Menteri.

Dalam UU Ketenagakerjaan pada Pasal 90 diatur pula larangan bagi pengusaha untuk memberikan upah di bawah ketentuan upah minimum. Namun demikian bagi pengusaha yang tidak mampu membayar upah minimum, dapat dilakukan penangguhan. Penangguhan pembayaran upah minimum ditentukan dalam Keputusan Menteri Tenaga Kerja dan Transmigrasi Nomor KEP.231/MEN/2003 tentang Tata Cara Penangguhan Pelaksanaan Upah Minimum.

Untuk menentukan besaran upah minimum, selain harus dengan mempertimbangkan kesejahteraan pekerja/buruh, pemerintah juga harus memperhitungkan kemampuan dan kelangsungan hidup perusahaan. Jika upah minimum yang ditetapkan terlalu rendah maka para pekerja/buruh akan sulit untuk mencapai kehidupan yang sejahtera. Demikian juga sebaliknya, jika upah minimum ditetapkan terlalu besar maka akan dapat memengaruhi komponen biaya produksi yang semakin tinggi yang akan berdampak pada harga jual produksi yang tinggi.

Pengusaha dan pekerja/buruh dapatmelakukankesepakatanmengenai pengupahan, akan tetapi kesepakatan tersebut tidak dibenarkan bila lebih rendah dari ketentuan pengupahan yang ditetapkan dalam peraturan perundang-undangan yang berlaku. Sehingga bila terdapat kesepakatan yang lebih rendah atau bertentangan dengan peraturan perundang-undangan maka kesepakatan yang dibuat tersebut menjadi batal demi hukum. Selanjutnya pengusaha berkewajiban melaksanakan pembayaran upah bagi pekerja/buruh sesuai dengan ketentuan dalam peraturan perundangan yang berlaku.

Asas pembayaran dilakukan atas dasar pekerjaan tidak berlaku terhadap: 
a. pekerja/buruh sakit sehingga tidak dapat melakukan pekerjaan;

b. pekerja/buruh perempuan yang sakit pada haripertama dan kedua masa haid nya sehingga tidak dapat melakukan pekerjaan;

c. pekerja/buruh tidak masuk bekerja karena pekerja/ buruh menikah, menikahkan, mengkhitankan, membaptiskan anaknya, istri melahirkan atau keguguran kandungan, suami atau istri atau anak atau menantu atau orang tua atau mertua atau anggota keluarga dalam satu ruma meninggal dunia;

d. pekerja/buruh tidak dapat melakukan pekerjaannya karena sedang menjalankan kewajiban terhadap Negara;

e. pekerja/buruh tidak dapat melakukan pekerjaanya karena menjalankan ibadah yang diperintahkan agamanya;

f. pekerja/buruh bersedia melakukan pekerjaan yang telah dijanjikan tetapi pengusaha tidak mempekerjakan nya baik karena kesalahan sendiri maupun halangan yang seharusnya dapat dihindari pengusaha;

g. pekerja/buruh melaksanakan hak istirahat;

h. pekerja/buruh melaksanakan tugas serikat pekerja/serikat buruh atas persetujuan pengusaha; dan i. pekerja/buruh melaksanakan tugas pendidikan dari perusahaan.

Terhadap pengecualian tersebut maka upah pekerja/buruh tetap wajib dibayarkan oleh pengusaha. Dan ketentuan mengenai pengaturan pelaksanaan ketentuan pengecualian tersebut ditetapkan melalui perjanjian kerja, peraturan perusahaan, atau perjanjian kerja bersama.

Salah satu hal penting tentang pengaturan pengupahan adalah pembentukan Dewan Pengupahan Nasional, Provinsi, dan Kabupaten/ Kotayang terdiriatas unsur pemerintah, organisasi pengusaha, serikat pekerja/ serikat buruh, perguruan tinggi, dan pakar. Menurut Keputusan Presiden Nomor 107 Tahun 2004 tentang Dewan Pengupahan, Dewan Pengupahan adalah suatu lembaga non struktural yang bersifat tripartite. Depenas (Dewan Pengupahan Nasional) bertugas memberikan saran, dan pertimbangan kepada Pemerintah dalam rangka perumusan kebijakan pengupahan dan pengembangan sistem pengupahan nasional. Dan dalam melaksanakan tugasnya, Depenas dapat bekerja sama baik dengan instansi Pemerintah maupun swasta dan pihak terkait lainnya jika dipandang perlu. Pembahasan rumusan saran dan pertimbangan di Depenas dilaksanakan melalui tahapan sebagai berikut :

a. Unsur Pemerintah dan/ atau unsur Serikat Pekerja/ 
Serikat Buruh dan/atau unsur Organisasi Pengusaha dan/atau unsur Perguruan Tinggi/Pakar menyiapkan bahan untuk dibahas dalam rapat Depenas.

b. Hasil pembahasan tersebut dituangkan dalam bentuk pokokpokok pikiran Depenas.

c. Pokok-pokok pikiran tersebut disampaikan kepada Pemerintah dalam bentuk rekomendasi sebagai saran dan pertimbangan dalam rangka perumusan kebijakan pengupahan.

Sementara itu Depeprov (Dewan Pengupahan Provinsi) bertugas untuk:

a. Memberikan saran dan pertimbangan kepada gubernur dalam rangka : 1) Penetapan Upah Minimum Provinsi (UMP).

2) Penetapan Upah Minimum Kabupaten /Kota (UMK) dan Upah Minimum Sektoral (UMS).

3) Penerapan sistem pengupahan di tingkat Provinsi.

b. Menyiapkan bahan perumusan pengembangan sistem pengupahan nasional.

Sedangkan Depekab/Depeko (Dewan Pengupahan Kabupaten/Kota) bertugas :

a. Memberikan saran dan pertimbangan kepada Bupati/ Walikota dalam rangka : 1) pengusulan Upah Minimum Kabupaten/Kota (UMK) dan/ atau Upah Minimum Sektoral Kabupaten/Kota (UMSK); 2) penerapan sistem pengupahan di tingkat Kabupaten/Kota.

b. Menyiapkan bahan perumusan pengembangan sistem pengupahan nasional.

Dalam melaksanakan tugasnya, baik Depeprov maupun Depekab/ Depeko dapat bekerja sama baik dengan instansi Pemerintah maupun swasta dan pihak terkait lainnya jika dipandang perlu. Perlindungan upah di Indonesia menurut Asri Wijayanti terdapat dalam tiga aspek yaitu penentuan upah minimum, waktu kerja, dan denda. ${ }^{6}$

\subsection{Korelasi Pengaturan Upah dan Investasi di Indonesia \\ Investasi di Indonesia diatur} dalam Undang-Undang Nomor 25 Tahun 2007 tentang Penanaman Modal. Dalam kaitan dengan ketenagakerjaan, undang-undang tersebut telah mengaturnya dalam Pasal 11 dan Pasal 12. Menurut Henny Maria Nastasia Anastasia ${ }^{7}$ yang mengutip temuan JETTRO (2005), disebutkan bahwa permasalahan utama investasi di Indonesia adalah permasalahan peningkatan upah buruh yang menempatiurutan pertama dengan 84,4 $\%$. Penyerapan tenaga kerja juga tidak lepas dari peranan pemerintah sebagai

6 Asri Wijayanti, Op. Cit., hlm. 109-117.

7 Henny Maria Anastasia, Faktor-Faktor Ekonomi Makro yang Mempengaruhi Investasi Asing Langsung (FDI) pada Sektor Perkebunan di Indonesia Periode (Tahun 1980 -2007), Universitas Indonesia, diakses melalui http://lib.ui.ac.id/file?file=digital/20300265T\%2030514-Faktor-faktor-full\%20text.pdf, pada tanggal 19 April 2015, hlm. 5. 
penyusun kebijakan untuk mendukung investasi yang baik, standar pendapatan untuk kesejahteraan tenaga kerja dan strategi-strategi yang dilakukan untuk mencapai pertumbuhan ekonomi yang tinggi. Kebijakan pemerintah dalam menetapkan upah minimum menjadi alasan bagi pengusaha untuk lebih memilih industri yang padat modal.

\section{Aktivitas investasi yang}

dilakukan oleh masyarakat secara terus-menerus akan berpengaruh pada peningkatan aktivitas ekonomi dan kesempatan kerja, peningkatan pendapatan nasional, dan peningkatan tingkat kesejahteraan masyarakat. Pada umumnya investasi mempunyai tiga fungsi penting yaitu (1) investasi sebagai salah satu bagian dari pengeluaran agregat, sehingga peningkatan investasi berakibat pada peningkatan permintaan agregat, pendapatan nasional, dan kesempatan kerja; (2) bertambahnya barang modal sebagai akibat investasi akan berpengaruh pada peningkatan kapasitas produksi; (3) investasi selalu diiringi dengan berkembangnya teknologi. ${ }^{8}$

Teori Lewis tentang ketenagakerjaan mengungkapkan bahwa kelebihan pekerja merupakan kesempatan dan bukan masalah. Kelebihan pekerja satu sektor akan memberikan andil terhadap pertumbuhan output dan penyediaan pekerja di sektor lain. Selanjutnya

8 Sadono Sukirno, 1996, Pengantar Teori Makroekonomi, RajaGrafindo Persada, Jakarta, hlm.33.
Lewis mengemukakan bahwa ada dua sektor di dalam perekonomian negara sedang berkembang, yaitu sektor modern dan sektor tradisional. ${ }^{9}$ Sektor tradisional tidak hanya berupa sektor pertanian di pedesaan, melainkan juga termasuk sektor informal di perkotaan (pedagang kaki lima, pengecer, pedagang angkringan). Sektor informal mampu menyerap kelebihan tenaga kerja yang ada selama berlangsungnya proses industrialisasi,

Pemerintah memiliki fungsi utama untuk membentuk kebijakan dalam mengatur hubungan antara pekerja/buruh dengan pengusaha agar berjalan serasi dan seimbang yang didasari dengan pengaturan hak dan kewajiban secara adil serta berperan sebagai penegak hukum. Di samping itu pemerintah juga berperan sebagai penengah yang adil dalam penyelesaian konflik atau perselisihan yang terjadi. Pada dasarnya keberlangsungan proses produksi demi kepentingan yang lebih luas juga harus pemerintah jaga dengan baik. Tujuan pekerja/ buruh untuk bekerja dalam untuk meningkatkan kesejahteraannya. Sedangkan pengusaha dalam proses produksi bertujuan memperoleh keuntungan dengan produktivitas yang tinggi. ${ }^{10}$ Hubungan industrial tersebut

9 Febry Wijayanti dkk., Analisis Penyerapan Tenaga Kerja Industri Dan Umkm Dalam Perekonomian Dua Sektor Di Jawa Timur, International Journal of Social and Local Economic Governance (IJLEG), vol. 1, no. 2, edisi Oktober 2015, hlm. 121, http://ijleg.ub.ac.id/index.php/ijleg/article/ download/17/46, diakses tanggal 29 Juli 2017

10 Asri Wijayanti, Op. Cit., hlm. 106. 
perlu diatur dengan tujuan akhir terwujudnya produktivitas atau kinerja perusahaan dalam bentuk peningkatan produktivitas serta kesejahteraan bagi pekerja/buruh dan pengusaha secara proporsional. Ketenangan kerja dan berusaha (industrial peace) perlu diciptakan untuk dapat mewujudkan tujuan akhir tersebut. Peningkatan produktivitas dan kesejahteraan merupakan dua hal yang saling berhubungan, keduanya tidak dapat dipisahkan satu dengan yang lainnya dan malah saling memengaruhi. Produktivitas perusahaan yang dimulai dengan produktivitas kerja hanya dapat dicapai jika didukung dengan kondisi pekerja/buruh yang sejahtera maupun dengan adanya harapan yang nyata terhadap adanya peningkatan kesejahteraan di waktu mendatang.

Upah diberikan menurut kesepakatan para pihak, untuk menghindari upah yang terlalu rendah maka pemerintah telah menetapkan batasan standard upah terendah dalam peraturan perundang-undangan, ${ }^{11}$ salah satunya dalam Peraturan Menteri Nomor 7 Tahun 2013 tentang Upah Minimum dan Peraturan Menteri Tenaga Kerja dan Transmigrasi Nomor 1 Tahun 2017 tentang Struktur dan Skala Upah. Pemerintah sebagai regulator berperan sebagai penengah dalam kebijakan pengupahan yang harus mampu mengakomodasi kepentingan buruh/pekerja dengan

11 Lalu Husni, 2016, Pengantar Hukum Ketenagakerjaan, RajaGrafindo Persada, Jakarta, hlm. 144-145. pengusaha. Upah yang terlalu tinggi dapat memengaruhi investasi karena mengakibatkan biaya produksi menjadi tinggi. Sedangkan upah yang terlalu tinggi akan memengaruhi kesejahteraan pekerja/buruh. Untuk itu maka dalam kondisi pengusaha tidak mampu membayar upah minimum, pemerintah telah mengeluarkan kebijakan penangguhan pembayaran upah. Akan tetapi hal itu harus diiringi dengan penegakan hukum secara tegas apabila terjadi penangguhan upah dilakukan hanya semata untuk menghindari kewajiban pengusaha.

Kesejahteraan para pekerja/ buruh dan pengusaha hanya mungkin dapat dicapaijika didukung oleh tingkat produktivitas tertentu, maupun dengan adanya peningkatan produktivitas yang memadai mengarah pada tingkat produktivitas yang ingin dicapai. Produktivitas tersebut akan dapat mendorong kegiatan bisnis sehingga mampu menarik investor melakukan penanaman modal. Alasan investasi menurut Kamaruddin Ahmad antara lain karena bertujuan memperoleh kehidupan lebih layak pada waktu mendatang, mengurangi tekanan inflasi, dan untuk menghemat pajak. ${ }^{12}$

\section{KESIMPULAN}

1. Instrumen pengaturan pengupahan di Indonesia telah cukup memadai. Akan tetapi salah satu hal penting yang

12 Kamaruddin Ahmad, 2004, Dasar-dasar Manajemen Investasi dan Portofolio, Rineka Cipta, Jakarta, hlm. 4. 
harus dilakukan pemerintah adalah penegakan hukum atas ketentuan tentang pengupahan. Hal itu penting dilakukan agar keseimbangan antara pekerja/ buruhdengan pengusahatercapai. Investasi dan pengupahan merupakan dua hal berbeda yang saling memengaruhi, untuk itu pemerintah sebagai regulator harus dapat bersikap adil dalam menegakkan peraturan perundangan.

2. Pengaturan pengupahan berperan dalam investasi di Indonesia, yaitu agar investasi semakin berkembang dan berpengaruh pada peningkatan kesejahteraan masyarakat pada umumnya.

\section{DAFTAR PUSTAKA}

\section{Buku}

Ahmad, Kamaruddin, 2004, Dasardasar Manajemen Investasi dan Portofolio, Rineka Cipta, Jakarta.

Husni, Lalu, 2016, Pengantar Hukum Ketenagakerjaan, RajaGrafindo Persada, Jakarta.

Manan, Abdul, 2014, Peranan Hukum dalam Pembangunan Ekonomi, Kencana Prenadamedia Group, Jakarta.

Sihombing, Jonker, 2010, Peran dan Aspek Hukum dalam Pembangunan Ekonomi, Alumni, Bandung.

Sukirno,Sadono, 1996,PengantarTeori Makroekonomi, RajaGrafindo Persada, Jakarta.
Susanti, Dyah Ochtorina dan A'an Efendi, 2014, Penelitian Hukum (Legal Research), Sinar Grafika, Jakarta.

Wijayanti, Asri, 2016, Hukum Ketenagakerjaan Pasca reformasi, Sinar Grafika, Jakarta.

\section{Jurnal dan karya ilmiah}

Wijayanti, Febry dkk., Analisis Penyerapan Tenaga Kerja Industri Dan Umkm Dalam Perekonomian Dua Sektor Di Jawa Timur,International Journal of Social and Local Economic Governance (IJLEG), vol. 1, no. 2, edisi Oktober 2015, hlm. 121, http://ijleg.ub.ac.id/index.php/ ijleg/article/download/17/46, diakses tanggal 29 Juli 2017.

Anastasia, Henny Maria, FaktorFaktor Ekonomi Makro yang Mempengaruhi Investasi Asing Langsung (FDI) pada Sektor Perkebunan di Indonesia Periode (Tahun 1980-2007), (Tesis) Universitas Indonesia, diakses melalui http://ib.ui.ac. id/file?file $=$ digital $/ 20300265$ T\%2030514-Faktor-faktorfull $\% 20$ text.pdf, pada tanggal 19 April 2015

\section{Peraturan Perundang-Undangan}

Undang-Undang Nomor 13 Tahun 2003 tentang Ketenagakerjaan, Lembaran Negara Republik Indonesia Tahun 2003 Nomor 39. 
Undang-Undang Nomor 25 Tahun 2007 tentang Penanaman Modal, Lembaran Negara Republik Indonesia Tahun 2007 Nomor 67.

Peraturan Pemerintah Nomor 78 Tahun 2015 tentang Pengupahan, Lembaran Negara Republik Indonesia Tahun 2015 Nomor 237.

Keputusan Presiden Nomor 107 Tahun 2004 tentang Dewan Pengupahan.

Peraturan Menteri Nomor 7 Tahun 2013 tentang Upah Minimum, Berita Negara Republik Indonesia Tahun 2013 Nomor 1239.

Peraturan Menteri Tenaga Kerja dan Transmigrasi Nomor 1 Tahun 2017 tentang Struktur dan Skala Upah, Berita Negara Tahun 2017 Nomor 441.

Keputusan Menteri Tenaga Kerja dan Transmigrasi Nomor KEP.231/ MEN/2003 tentang Tata Cara Panangguhan Pelaksanaan Upah Minimum. 